\title{
Opinion Statement of the Effect of Mechanical Stress on Cartilage Tissue Engineering
}

\author{
Kosei Ando*, Tomohiro Mimura, Yoshitaka Matsusue and Kanji Mori \\ Department of Orthopaedic Surgery, Shiga University of Medical Science, Otsu, Shiga, 520-2192, Japan
}

\begin{abstract}
Articular cartilage is characterized by its poor capacity for self-repair. Once articular cartilage is injured and defected, it cannot be spontaneously repaired and finally develops osteoarthritis (OA). OA is a major leading cause of severe activity limitations and disability, resulting in worldwide socio-economical burden. At present, there is no established therapy for adequate repair of damaged articular cartilage. Researchers have therefore attempted to establish the cartilage tissue engineering as an effective alternative treatment of cartilage repair. However, the articular cartilage repair still remains a clinical and scientific challenge.

In cartilage tissue engineering, it is believed that cell source, scaffold and growth factors are three key factors for the desired result of cell therapy for the damaged cartilage repair. However, increasing evidence is showing that these key factors are not enough and other factors may be required to achieve the optimal outcome. Since normal articular cartilage is always subjected to mechanical stress in daily activities, mechanical stress has attracted much attention as fourth key factor in cartilage tissue engineering. However, the real impact of mechanical stress on cartilage tissue engineering is far from complete understanding.
\end{abstract}

In this review, we summarize the accumulating knowledge of the effect of mechanical stress on cartilage tissue engineering and discuss about the challenges for the future.

Keywords: Articular cartilage, tissue engineering, mechanical stress, and chondrocytes.

\section{INTRODUCTION}

Articular cartilage, consisting of chondrocytes and hydrated extracellular matrix (ECM) such as type II collagen, glycosaminoglycan (GAG) and water is characterized by its poor capacity of self-repair due to the lack of blood supply and nerves [1]. Unfortunately, once articular cartilage is injured and defected, it cannot be spontaneously repaired [2]. Indeed, the damage of articular cartilage caused by trauma often accelerates its degenerative process and finally develops osteoarthritis (OA) [3].

$\mathrm{OA}$, one of the most common joint diseases, seriously interferes with activity of daily living (ADL) and quality of life (QOL). Indeed, approximately 20 million of people in the United States are affected by OA [4]. The World Health Organization (WHO) estimates that approximately one in every ten people over 60 years in the world suffers OA [5]. $\mathrm{OA}$ is therefore one of the major leading causes of severe activity limitations and disability, thus resulting in worldwide socio-economical burden.

Once severe $\mathrm{OA}$ is established, currently available exclusive treatment is prosthetic joint replacement. However, prosthetic joint replacement has just "replaced", not "repaired" the involved joint, and it has several potential problems such as loosening and infection [6-9]. In turn, to

*Address correspondence to this author at the Department of Orthopaedic Surgery, Shiga University of Medical Science, Otsu, Shiga, 520-2192, Japan; Tel: +81-77-548-2252; Fax: +81-77-548-2254; E-mail: andoko@mx.scn.tv establish the optimal treatment for OA, repair of the damaged cartilage is essential. A number of therapeutic techniques for damaged cartilage have been developed, e.g., drilling [10], microfracture [11], osteochondral graft [12], periosteal graft [13], or autologous chondrocyte implantation (ACI) [14]. However, a successful articular cartilage repair still remains a clinical and scientific challenge.

In turn, the progress in the field of tissue engineering has shown the possibilities for the treatment of cartilage defects [14]. We have summarized representative animal studies of tissue engineering for articular cartilage defect using chondrocytes (Table 1) [15-26]. Since the pioneering work of the ACI, a diversity of cell therapies has been invented [27-29].

In 1960s, it was found that chondrocytes cultured in monolayer condition rapidly dedifferentiated and lost their characters [30, 31]. After the dedifferentiation of chondrocytes, the cells lose the ability of maintaining the cartilagespecific ECM such as GAG and type II collagen, whereas they acquire fibroblastic morphology and mainly synthesize type I collagen [32-34]. Subsequent studies [34, 35] have revealed that three-dimensional (3D) culture with scaffold (i.e., collagen gel) reduces this dedifferentiation process (Fig. 1). However, 3D culture could not completely eliminate cell-dedifferentiation. Additional modifications which ameliorate the quality of tissue-engineered cartilage were required. Several factors were tested to increase the quality of tissue-engineered cartilage [32-44]. In turn, it is believed that cell source (i.e., mesenchymal cell) [35-39], scaffold (i.e., collagen gel, agarose gel) [32-34] and growth factors (i.e., basic fibroblast growth factor (bFGF), bone morphogenetic protein-2, insulin-like growth factor-I, transforming 
Table 1. Representative Animal Studies of Tissue Engineering for Articular Cartilage Defect Using Chondrocytes

\begin{tabular}{|c|c|c|c|c|c|c|c|}
\hline Author & Cells & Graft & Animal & Joint & Scaffold & Main findings \\
\hline \hline Chesterman PJ & chondrocytes & allo & rabbit & shoulder & free & fibrous tissue \\
\hline Wakitani S & chondrocytes & allo & rabbit & knee & collagen gel & hyaline-like tissue & {$[15]$} \\
\hline Hendrickson DA & chondrocytes & allo & horse & knee & fibrin glue & hyaline-like tissue & {$[16]$} \\
\hline Kawamura S & chondrocytes & allo & rabbit & knee & collagen gel & hyaline-like tissue & hyaline-like tissue \\
\hline Wakitani S & chondrocytes & allo & rabbit & knee & collagen gel & collagen gel & hyaline-like tissue \\
\hline Katsube K & chondrocytes & allo & rabbit & knee & he] & hyaline-like tissue \\
\hline Grigolo B & chondrocytes & auto & rabbit & knee & hyaluronic acid & [21] \\
\hline Mierisch CM & chondrocytes & allo & rabbit & knee & alginate beads & mix of hyaline and fibrous & [22] \\
\hline Lee CR & chondrocytes & auto & canine & knee & collagen gel & mix of hyaline and fibrous & [23] \\
\hline Willers C & chondrocytes & auto & rabbit & knee & collagen gel & hyaline-like tissue & [24] \\
\hline De Franceshi L & chondrocytes & auto & rabbit & knee & collagen gel & fibrocartilagenous tissue & {$[25]$} \\
\hline Dorotka R & chondrocytes & auto & ovine & knee & collagen gel & hyaline-like tissue & {$[26]$} \\
\hline
\end{tabular}

growth factor- $\beta 1$ ) [40-44] are three key factors for the better quality of tissue-engineered cartilage, which govern the result of cell therapy for the damaged cartilage repair [3244]. However, accumulating results have shown that these key factors are not enough and additional factors may be required to achieve the optimal outcome.

Normal articular cartilage is always subjected to mechanical stress in daily activities. In turn, mechanical stress has attracted much attention as fourth key factor in cartilage tissue engineering. However, the effect of mechanical stress on cartilage tissue engineering is far from complete understanding (Fig. 2). In this review, we summarize the accumu- lating knowledge of the effect of mechanical stress on cartilage tissue engineering and discuss the challenges for the future.

\section{MECHANICAL STRESS ON ARTICULAR CARTILAGE IN PHYSIOLOGICAL CONDITION}

Articular cartilage is always exposed to various types of mechanical stimuli. During routine activities under normal physiological conditions, mechanical stimuli on articular cartilage can exert peak dynamic mechanical stresses of up to 18 megapascals (MPa) [45]. Furthermore, static physio-

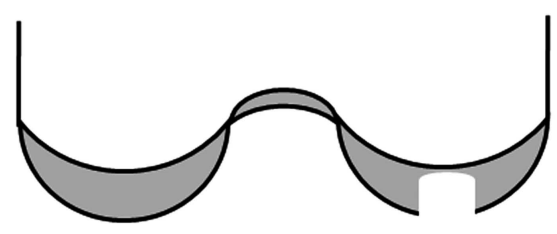

Cartilage defect
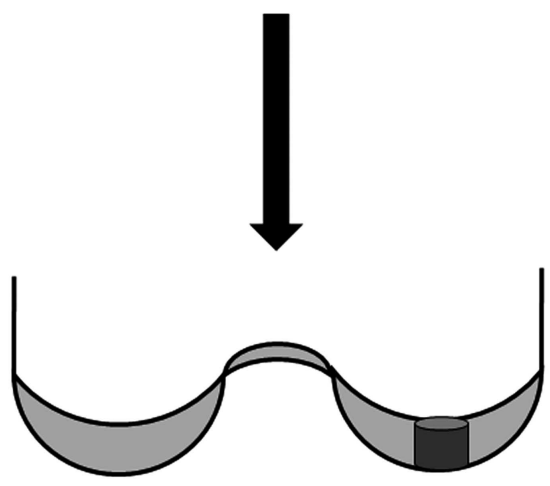

Implantation



Cell proliferation
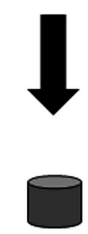

3D construct

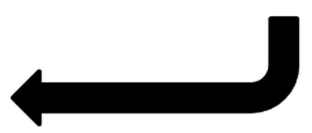

Fig. (1). Schematic presentation of cartilage repair using tissue-engineered 3D constructs. 


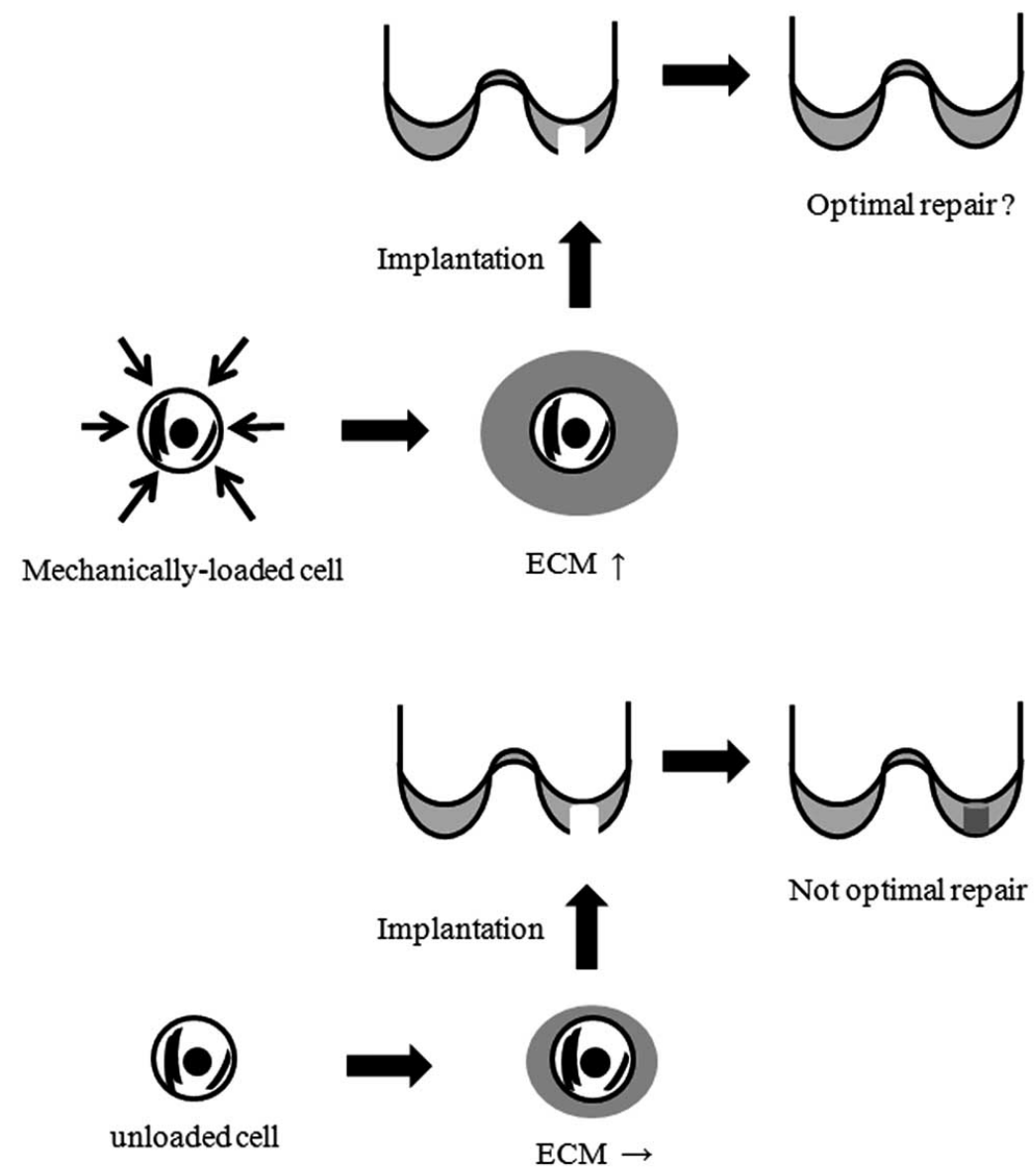

Fig. (2). Schematic presentation of cartilage repair using tissue-engineered chondrocytes. The quality of tissue-engineered chondrocytes before implantation governs the result of cell therapy for the damaged cartilage repair. Better quality of tissue-engineered chondrocytes [extracellular matrix (ECM) rich] under mechanical stress compared to those without mechanical stress might contribute to the optimal repair.

logical stresses applied to knee joints for 5-30 min can result in approximately compressive strains of $40 \%$ in certain knee cartilages [46]. On the other hand, in vivo joint immobilization and reduction of joint loading resulted in a rapid loss and degradation of ECM content, whereas moderate exercise stimulated ECM synthesis [47-49]. Accordingly, it is considered that mechanical stress plays an important role in cartilage homeostasis [50-52] and the lack of appropriate mechanical stress in previous culture systems in cartilage tissue engineering might be one of the causes of failure.

Mechanical stress can be divided into roughly two types; static and dynamic loading. The former is stimulus represented by standing; the latter is stimulus represented by walking or running. In recent studies [60-80], many researchers have attempted to determine the influence of these mechanical stresses on cartilage tissue engineering.

\section{STATIC COMPRESSIVE LOAD}

Previous studies have revealed that the ECM synthesis by chondrocytes under static compression load varied depending on the time length of stimulation [53, 54, 60, 61].

In particular, Ragan et al. [53] showed that both aggrecan and type II collagen mRNA expressions were up-regulated during the first $30 \mathrm{~min}$ of static compression, whereas they were significantly down-regulated $4 \mathrm{~h}$ to $24 \mathrm{~h}$ after the initial static compression. Valhmu et al. [54] reported that aggrecan mRNA expression temporarily increased $1 \mathrm{~h}$ after the initial static compression, however after $24 \mathrm{~h}$ long-term static compression had no significant change on it. Similarly, Fitzgerald et al. [61] demonstrated that ECM proteins were increased 2-3 fold during the first $8 \mathrm{~h}$ of $50 \%$ static compression. However, after $24 \mathrm{~h}$ of the static compression, ECM proteins were down-regulated, whereas ECM proteinases were highly up-regulated.

It remains unknown why chondrocytes showed differential response depending on the stimulating time.

\section{DYNAMIC COMPRESSIVE LOAD}

A number of studies [51, 52, 55-60, 63-73, 75-78, 80] have demonstrated that dynamic compressive loads enhanced the cartilage-specific ECM synthesis by chondrocytes in 3D scaffolds (i.e., collagen gel, agarose gel) or cartilage explants. Most researchers in these studies have reported that amplitude (i.e., 5-15\%) and/or frequency (i.e., 0.01-1 Hz) of dynamic compressive road govern ECM synthesis by chondrocytes. 
Specifically, Buschmann et al. [57] demonstrated that 6\% maximum strain of cyclic compression elevated GAG synthesis by chondrocytes embedded in agarose gel at 0.01-1 Hz. Elder et al. [63] demonstrated that low amplitude cyclic compression at $0.33 \mathrm{~Hz}$ promoted GAG synthesis of mesenchymal cells from chick limb bud embedded in agarose gel. Furthermore, we also found that cyclic compressive loading of $5 \%$ amplitude in cycles of $3 \mathrm{~s}$ stimulated cartilage-specific ECM synthesis by chondrocytes embedded in type I collagen gel [76].

In contrast, only a few researchers reported that dynamic compressive loads were ineffective [58-60, 67]. Lee et al. [58] found that $15 \%$ dynamic compressive loading inhibited PG synthesis by chondrocytes embedded in agarose gel at $0.3 \mathrm{~Hz}$ and had no effect on it at $3 \mathrm{~Hz}$, whereas stimulated it at $1 \mathrm{~Hz}$. Hunter et al. [60] also demonstrated that $25 \%$ dynamic compressive loading at $1 \mathrm{~Hz}$ had no effect for cartilagespecific gene expressions in 3D collagen gel.

The cause of this discrepancy remains to be determined. However, the differences of animal species, experimental conditions or lack of strict control have been suggested as likely explanations [67]. Thus, the optimal conditions, ( $i$ e., frequency, amplitude or timing etc.) for up-regulation of cartilage-specific ECM synthesis by chondrocytes to achieve "optimal tissue-engineered cartilage" remains to be determined. For the moment, most researchers seem that dynamic compressive loads with moderate frequency $(0.01-1 \mathrm{~Hz})$ and low amplitude (up to $15 \%$ peak to peak compression) achieve the best results.

Furthermore, recent studies [62, 81-86] have also revealed how mechanical stimulation can act on chondrocytes. Mechanical stimulation is converted to biochemical signal via mechanotransduction, which results in the activation of intracellular signaling pathways such as mechanoreceptors ( $i$ e., integrins) [81], ion channels (slow conductance $\mathrm{Ca}^{2+}$ sensitive $\mathrm{K}^{+}$and stretch-activated ion channels) [82], soluble mediators [bFGF, interleukin-4 (IL-4)] [83, 84], and intracellular protein kinases (mitogen-activated protein kinase (MAPK) family) [62, 85]. Consequently, these intracellular signaling pathways modulate various biochemical activities in chondrocyte behavior. Salter et al. have demonstrated that integrin-associated signaling pathways, activation of stretchactivated ion channels and autocrine/paracrine activity of IL4 are involved in the cellular response of human articular chondrocytes cultured in monolayer condition to dynamic load [86]. Further investigation to clarify the precise mechanisms of signaling pathways activated by mechanical stress might contribute to achieve a "better tissue-engineered cartilage".

\section{SUMMARY AND FUTURE VISION}

Many cells in our body are exposed to mechanical stress during physiological activities and respond to them in different ways. Especially, tissues which function as a supportive tissue, $i$ e., bone or cartilage use this stimulation during tissue formation and maintenance. As mentioned above, a number of studies have shown the effects and mechanisms of mechanotransduction in cartilage or three dimensional engineered tissues. Furthermore, these biological responses to mechanical stimulation are thought to enhance cartilage formation or regeneration. In turn, mechanical stimulation of a cultured tissue is thought to be a feasible strategy to develop a new and most effective cartilage therapy. Further studies are needed to elucidate precise mechanism as well as optimal conditions of mechanical stress for "best tissue-engineered cartilage".

\section{REFERENCES}

[1] Mankin HJ. The response of articular cartilage to mechanical injury. J Bone Joint Surg 1982; 64A: 460-6.

[2] Hunter W. Of the structure and diseases of articulating cartilages. Phil Trans 1743; 470: 514-21.

[3] Buckwalter JA, Lane NE. Athletics and osteoarthritis. Am J Sports Med 1997; 25: 873-81.

[4] Lawrence RC, Helmick CG, Arnett FC, et al. Estimates of the prevalence of arthritis and selected musculoskeletal disorders in the United States. Arthritis Rheum 1998; 41: 778-99.

[5] World; World Health Report Archives 1995-2000. 2001. Available from; http://www.who.int/whr2001/2001/archives/1997/factse.htm.

[6] Gruen TA, McNeice GM, Amstutz HC. "Modes of failure" of cemented stem-type femoral components: a radiographic analysis of loosening. Clin Orthop Relat Res 1979; 141: 17-27.

[7] Garvin KL, Hanssen AD. Infection after total hip arthroplasty. Past, present, and future. J Bone Joint Surg Am 1995; 77: 1576-88.

[8] Ali Khan MA, Brakenbury PH, Reynolds IS. Dislocation following total hip replacement. J Bone Joint Surg Br 1981; 63: 214-18.

[9] Wroblewski BM, Siney PD, Fleming PA. Charnley low-frictional torque arthroplasty in patients under the age of 51 years. Follow-up to 33 years. J Bone Joint Surg 2002; 84-B: 540-3.

[10] Pridie KH. A method of resurfacing osteoarthritic knee joints. J Bone Joint Surg 1959; 41B: 618-9.

[11] Rodrigo JJ, Steadman JR, Silliman JF. Improvement of fullthickness chondral defect healing in the human knee after debridement and microfracture using continuous passive motion. Am J Knee Surg 1994; 7: 109-16.

[12] Matsusue Y, Yamamuro Y, Hama H. Arthroscopic multiple osteochondral transplantation to the chondral defects in the knee associated with anterior cruciate ligament disruption. Arthroscopy 1993; 9: 318-21.

[13] O'Driscoll SW, Keeley FW, Salter RB. Durability of regenerated articular cartilage produced by free autogeneous periosteal grafts in major full-thickness defects under the influence of continuous passive motion. J Bone Joint Surg 1988; 70A: 595-606.

[14] Brittberg M, Lindahl A, Nilsson A, et al. Treatment of deep cartilage defects in the knee with autologous chondrocyte transplantation. N Engl J Med 1994; 331: 889-95.

[15] Chesterman PJ, Smith AU. Homotransplantation of articular cartilage and isolated chondrocytes. An experimental study in rabbits. J Bone Joint Surg Br 1968; 50: 184-97.

[16] Wakitani S, Goto T, Pineda SJ, et al. Mesenchymal cell-based repair of large, full-thickness defects of articular cartilage. J Bone Joint Surg Am 1994; 76: 579-92.

[17] Hendrickson DA, Nixon AJ, Grande DA, et al. Chondrocyte-fibrin matrix transplants for resurfacing extensive articular cartilage defects. J Orthop Res 1994; 12: 485-97.

[18] Kawamura S, Wakitani S, Kimura T, et al. Articular cartilage repair. Rabbit experiments with a collagen gel-biomatrix and chondrocytes cultured in it. Acta Orthop Scand 1998; 69: 56-62.

[19] Wakitani S, Goto T, Young RG, et al. Repair of large full-thickness articular cartilage defects with allograft articular chondrocytes embedded in a collagen gel. Tissue Eng 1998; 4: 429-44.

[20] Katsube K, Ochi M, Uchio Y, et al. Repair of articular cartilage defects with cultured chondrocytes in Atelocollagen gel. Comparison with cultured chondrocytes in suspension. Arch Orthop Trauma Surg 2000; 120: 121-7.

[21] Grigolo B, Roseti L, Fiorini M, et al. Transplantation of chondrocytes seeded on a hyaluronan derivative (hyaff-11) into cartilage defects in rabbits. Biomaterials 2001; 22: 2417-24.

[22] Mierisch CM, Wilson HA, Turner MA, et al. Chondrocyte transplantation into articular cartilage defects with use of calcium alginate: the fate of the cells. J Bone Joint Surg Am 2003; 85A: 1757-67. 
[23] Lee CR, Grodzinsky AJ, Hsu HP, et al. Effects of a cultured autologous chondrocyte-seeded type II collagen scaffold on the healing of a chondral defect in a canine model. J Orthop Res 2003; 21: 272-81.

[24] Willers C, Chen J, Wood D, et al. Autologous chondrocyte implantation with collagen bioscaffold for the treatment of osteochondral defects in rabbits. Tissue Eng 2005; 11: 1065-76.

[25] De Franceschi L, Grigolo B, Roseti L, et al. Transplantation of chondrocytes seeded on collagen-based scaffold in cartilage defects in rabbits. J Biomed Mater Res A 2005; 75: 612-22.

[26] Dorotka R, Windberger U, Macfelda K, et al. Repair of articular cartilage defects treated by microfracture and a three-dimensional collagen matrix. Biomaterials 2005; 26: 3617-29.

[27] Cherubino P, Grassi FA, Bulgheroni P, et al. Autologous chondrocyte implantation using a bilayer collagen membrane: A preliminary report. J Orthop Surg 2003: 11: 10-5.

[28] Ochi M, Uchio Y, Kawasaki K, et al. Transplantation of cartilagelike tissue made by tissue engineering in the treatment of cartilage defects of the knee. J Bone Joint Surg Br 2002; 84: 571-8.

[29] Marcacci M, Zaffagnini S, Kon E, et al. Arthroscopic autologous chondrocyte transplantation: technical note. Knee Surg Sports Traumatol Arthrosc 2002; 10: 154-9.

[30] Holtzer H, Abbot J, Lash J, Holtzer S. The loss of phenotypic traits by differentiated cells in vitro: I. Dedifferentiation of cartilage cells. Proc Natl Acad Sci USA 1960; 46: 1533-42.

[31] Abbot J, Holtzer H. The loss of phenotypic traits by differentiated cells: III. The reversible behavior of chondrocytes in primary cultures. J Cell Biol 1966; 28: 473-87.

[32] Mayne R, Vail MS, Mayne PM, et al. Changes in type of collagen synthesized as clones of chick chondrocytes grow and eventually lose division capacity. Proc Natl Acad Sci USA 1976; 73: 1674-8.

[33] von der Mark, Gauss V, Von der Mark H, et al. Relationship between cell shape and type of collagen synthesised as chondrocytes lose their cartilage phenotype in culture. Nature 1977; 267: 531-2.

[34] Benya PD, Shaffer JD. Dedifferentiated chondrocytes reexpress the differentiated collagen phenotype when cultured in agarose gels. Cell 1982; 30: 215-24.

[35] Kimura T, Yasui N, Ohsawa S, et al. Chondrocytes embedded in collagen gels maintain cartilage phenotype during long-term cultures. Clin Orthop 1984; 186: 231-9.

[36] Chung C, Beecham M, Mauck RL, et al. The Influence of degradation characteristics of hyaluronic acid hydrogels on in vitro neocartilage formation by mesenchymal stem cells. Biomaterials 2009; 30: 4287-96.

[37] Erickson IE, Huang AH, Chung C, et al. Differential maturation and structure function relationships in mesenchymal stem cell- and chondrocyte-seeded hydrogels. Tissue Eng 2009; 15: 1041-52.

[38] Erickson IE, Huang AH, Sengupta S, et al. Macromer density influences mesenchymal stem cell chondrogenesis and maturation in photocrosslinked hyaluronic acid hydrogels. Osteoarthritis Cartilage 2009; 17: 1639-48.

[39] Huang AH, Farrell MJ, Mauck RL Mechanics and mechanobiology of mesenchymal stem cell-based engineered cartilage. J Biomech 2009; 43: 128-36.

[40] Gooch KJ, Blunk T, Courter DL, et al. IGF-I and mechanical environment interact to modulate engineered cartilage development. Biochem Biophys Res Commun 2001; 286: 909-15.

[41] Bonassar LJ, Grodzinsky AJ, Frank EH, et al. The effect of dynamic compression on the response of articular cartilage to insulin-like growth factor-I. J Orthop Res 2001; 19: 11-7.

[42] Mauck RL, Nicoll SB, Seyhan SL, et al. Synergistic action of growth factors and dynamic loading for articular cartilage tissue engineering. Tissue Eng 2003; 9: 597-611.

[43] Martin I, Suetterlin R, Baschong W, et al. Enhanced cartilage tissue engineering by sequential exposure of chondrocytes to FGF-2 during 2D expansion and BMP-2 during 3D cultivation. J Cell Biochem 2001; 83: 121-8.

[44] Martin I, Vunjak- Novakovic G, Yang J, et al. Mammalian chondrocytes expanded in the presence of fibroblast growth factor 2 maintain the ability to differentiate and regenerate threedimensional cartilage tissue. Exp Cell Res 1999; 253: 681-8.

[45] Hodge WA. Contact pressures in the human hip joint measured in vivo. Proc Natl Acad Sci USA 1986; 83: 2879-83.
[46] Herberhold C, Faber S, Stammberger T, et al. In situ measurement of articular cartilage deformation in intact femoropatellar joints under static loading. J Biomech 1999; 32: 1287-95.

[47] Palmoski MJ, Colyer RA, Brandt KD. Joint motion in the absence of normal loading does not maintain normal articular cartilage. Arthritis Rheum 1980; 23: 325-34.

[48] Säämänen AM, Tammi M, Jurvelin J, et al. Proteoglycan alterations following immobilization and remobilization in the articular cartilage of young canine knee (stifle) joint. J Orthop Res 1990; 8: 863-73

[49] Behrens F, Kraft EL, Oegema TR Jr. Biochemical changes in articular cartilage after joint immobilization by casting or external fixation. J Orthop Res 1989; 7: 335-43.

[50] Broom N D, Myers D B. A study of the structural response of wet hyaline cartilage to various loading situations. Connect Tissue Res 1980; 7: 227-37.

[51] Kim YJ, Sah RL, Grodzinsky AJ, et al. Mechanical regulation of cartilage biosynthetic behavior: physical stimuli. Arch Biochem Biophys 1994; 311: 1-12.

[52] Sah RL, Kim YJ, Doong JY, et al. Biosynthetic response of cartilage explants to dynamic compression. J Orthop Res 1989; 7: 619-36.

[53] Ragan PM, Badger AM, Cook M, et al. Down-regulation of chondrocyte aggrecan and type-II collagen gene expression correlates with increases in static compression magnitude and duration. J Orthop Res 1999; 17: 836-42.

[54] Valhmu WB, Stazzone EJ, Bachrach NM, et al. Load-controlled compression of articular cartilage induces a transient stimulation of aggrecan gene expression. Arch Biochem Biophys 1998; 353: 2936.

[55] Palmoski MJ, Brandt KD. Effects of static and cyclic compressive loading on articular cartilage plugs in vitro. Arthritis Rheum 1984; 27: 675-81.

[56] Parkkinen JJ, Lammi MJ, Helminen HJ, et al. Local stimulation of proteoglycan in articular cartilage explants by dynamic compression in vitro. J Orthop Res 1992; 7: 610-20.

[57] Buschmann MD, Gluzband YA, Grodzinsky AJ, et al. Mechanical compression modulates matrix biosynthesis in chondrocyte/agarose culture. J Cell Sci 1995; 108: 1497-508.

[58] Lee DA, Bader DL. Compressive strains at physiological frequencies influence the metabolism of chondrocytes seeded in agarose. J Orthop Res 1997; 15: 181-8.

[59] Torzilli PA, Grigiene R, Huang C, et al. Characterization of cartilage metabolic response to static and dynamic stress using a mechanical explant test system. J Biomech 1997; 30: 1-9.

[60] Hunter CJ, Imler SM, Malaviya P, et al. Mechanical compression alters gene expression and extracellular matrix synthesis by chondrocytes cultured in collagen I gels. Biomaterials 2002; 23: 1249-59.

[61] Fitzgerald JB, Jin M, Dean D, et al. Mechanical compression of cartilage explants induces multiple time-dependent gene expression patterns and involves intracellular calcium and cyclic AMP. J Biol Chem 2004; 279: 19502-11.

[62] Li KW, Wang AS, Sah RL. Microenvironment regulation of extracellular signal-regulated kinase activity in chondrocytes: effects of culture configuration, interleukin-1, and compressive stress. Arthritis Rheum 2003; 48: 689-99.

[63] Elder SH, Goldstein SA, Kimura JH, et al. Chondrocyte differentiation is modulated by frequency and duration of cyclic compressive loading. Ann Biomed Eng 2001; 29: 476-82.

[64] Davisson T, Kunig S, Chen A, et al. Static and dynamic compression modulate matrix metabolism in tissue engineered cartilage. J Orthop Res 2002; 20: 842-8.

[65] Shelton JC, Bader DL, Lee DA. Mechanical conditioning influences the metabolic response of cell-seeded constructs. Cells Tissues Organs 2003; 175: 140-50.

[66] Waldman SD, Spiteri CG, Grynpas MD, et al. Long-term intermittent compressive stimulation improves the composition and mechanical properties of tissue-engineered cartilage. Tissue Eng 2004; 10: 1323-31.

[67] Ackermann B, Steinmeyer J. Collagen biosynthesis of mechanically loaded articular cartilage explants. Osteoarthritis Cartilage 2005; 13: 906-14.

[68] Plumb MS, Aspden RM. The response of elderly human articular cartilage to mechanical stimuli in vitro. Osteoarthritis Cartilage 2005; 13: 1084-91. 
[69] Kelly TA, Ng KW, Wang CC, et al. Spatial and temporal development of chondrocyte-seeded agarose constructs in freeswelling and dynamically loaded cultures. J Biomech 2006; 39: 1489-97.

[70] Waldman SD, Couto DC, Grynpas MD, et al. A single application of cyclic loading can accelerate matrix deposition and enhance the properties of tissue-engineered cartilage. Osteoarthritis Cartilage 2006; 14: 323-30.

[71] Sharma G, Saxena RK, Mishra P. Differential effects of cyclic and static pressure on biochemical and morphological properties of chondrocytes from articular cartilage. Clin Biomech 2007; 22: 24855.

[72] Xie J, Han Z, Kim SH, et al. Mechanical loading-dependence of mRNA expressions of extracellular matrices of chondrocytes inoculated into elastomeric microporous poly (L-lactide-coepsilon-caprolactone) scaffold. Tissue Eng 2007; 13: 29-40.

[73] Hirano Y, Ishiguro N, Sokabe M, et al. Effects of tensile and compressive strains on response of a chondrocytic cell line embedded in type I collagen gel. J Biotechnol 2008; 133: 245-52.

[74] Wang Y, de Isla N, Huselstein C, et al. Effect of alginate culture and mechanical stimulation on cartilaginous matrix synthesis of rat dedifferentiated chondrocytes. Biomed Mater Eng 2008; 18: S4754.

[75] Wei F, Golenberg N, Kepich ET, et al. Effect of intermittent cyclic preloads on the response of articular cartilage explants to an excessive level of unconfined compression. J Orthop Res 2008; 26 : 1636-42.

[76] Ando K, Imai S, Isoya E, et al. Effect of dynamic compressive loading and its combination with growth factor on the chondrocytic phenotype of three-dimensional scaffold-embedded chondrocytes. Acta Orthop 2009; 80: 724-33.
[77] Raizman I, De Croos JN, St-Pierre JP, et al. Articular cartilage subpopulations respond differently to cyclic compression in vitro. Tissue Eng 2009; 15: 3789-98.

[78] Wang PY, Chow HH, Lai JY, et al. Dynamic compression modulates chondrocyte proliferation and matrix biosynthesis in chitosan/gelatin scaffolds. J Biomed Mater Res 2009; 91: 143-52.

[79] Torzilli PA, Bhargava M, Park S, et al. Mechanical load inhibits IL-1 induced matrix degradation in articular cartilage. Osteoarthritis Cartilage 2010; 18: 97-105.

[80] Villanueva I, Gladem SK, Kessler J, et al. Dynamic loading stimulates chondrocyte biosynthesis when encapsulated in charged hydrogels prepared from poly(ethylene glycol) and chondroitin sulfate. Matrix Biol 2010; 29: 51-62.

[81] Salter DM, Hughes DE, Simpson R, et al. Integrin expression by human articular chondrocytes. Br J Rheumatol 1992; 31: 231-4.

[82] Wright M, Jobanputra P, Bavington C, et al. Effects of intermittent pressure-induced strain on the electrophysiology of cultured human chondrocytes: evidence for the presence of stretch-activated membrane ion channels. Clin Sci 1996; 90: 61-71.

[83] Millward-Sadler SJ, Wright MO, Lee $\mathrm{H}$, et al. Integrin-regulated secretion of interleukin 4: a novel pathway of mechanotransduction in human articular chondrocytes. J Cell Biol 1999; 141: 183-9.

[84] Vincent T, Hermansson M, Bolton M, et al. Basic FGF mediates an immediate response of articular cartilage to mechanical injury. Proc Natl Acad Sci USA 2002; 99: 8259-64.

[85] Vincent TL, Hermansson MA, Hansen UN, et al. Basic fibroblast growth factor mediates transduction of mechanical signals when articular cartilage is loaded. Arthritis Rheum 2004; 50: 526-33.

[86] Salter DM, Millward-Sadler SJ, Nuki G, et al. Integrin-interleukin4 mechanotransduction pathways in human chondrocytes. Clin Orthop Relat Res 2001; 391: 49-60.

Received: January 12, 2010

Revised: April 20, 2010

Accepted: April 26, 2010

(C) Ando et al.; Licensee Bentham Open.

This is an open access article licensed under the terms of the Creative Commons Attribution Non-Commercial License (http://creativecommons.org/licenses/by$\mathrm{nc} / 3.0 /$ ), which permits unrestricted, non-commercial use, distribution and reproduction in any medium, provided the work is properly cited. 